\title{
ANALISIS PENDAPATAN ASLI DAERAH TERHADAP ANGGARAN PENDAPATAN DAN BELANJA DAERAH 2013
}

\author{
Harinoto \\ Email : natawardhana@gmail.com
}

\begin{abstract}
Abstrak :The research took place in the department of finance and asset management revenue Malang trying to analyze the potential of local financial resources that support local revenues, analyze the contribution of revenue to the budget, analyzing the constraints faced in optimizing Regional Revenue receipts, as well as efforts to overcome obstacles PAD is in optimizing revenues. The research uses descriptive-qualitative analysis approach intends to obtain in-depth study of the potential sources of finance and its implications Budget (budget). This type of research is descriptive who tried to describe in depth the object of research at the present time based on the facts as they appear. The results showed that the potential sources of local finance in the current budget year, local tax receipts increased, but revenues from levies fluctuate so that the necessary strategic efforts are more progressive, following receipt of Income Results of Regional Wealth Management The Separated also experienced improvement and other local Revenue valid from year to year fluctuations, in terms of the level of local autonomy based on the reception area, Malang still low, considering the contribution of local revenues to the budget by an average of $9117 \%$, remaining at $90.18 \%$ contributed by sources other than those derived from the PAD, and there are still many obstacles faced in optimizing regional income, yet realistic in determining the revenue targets, are still high levels of leakage and breakouts, as well as reduced admission object types. Efforts to do is to strive for the determination of revenue targets made more realistic, eliminate leakage and break-out level, and strive for the type of object revenue from taxes and levies can be further improved.
\end{abstract}

Keyword: local revenues, budgets and self-reliance

\section{PENDAHULUAN}

Kebijakan memperkuat Otonomi Daerah dalam Negara Kesatuan Republik Indonesia melalui UU No. 32 Tahun 2004 tentang Pemerintahan Daerah dan UU No. 33 Tahun 2004 tentang Perimbangan Keuangan antara Pemerintah Pusat dan Daerah. Saat ini kewenangan daerah menjadi sangat luas, bidang pemerintahan kecuali masalah politik luar negeri, pertahanan keamanan, peradilan, moneter dan fiscal, agama, serta bidang lain yang strategis. Bidang pemerintahan yang wajib dilaksanakan oleh Daerah meliputi pekerjaan umum, kesehatan, pendidikan, dan kebudayaan, pertanian, perhubungan, industri dan perdagangan, penanaman modal, lingkungan hidup, pertanahan, koperasi, dan tenaga kerja (UU No.32.2004).

Dalam rangka memenuhi tuntutan pelayanan kepada masyarakat, maka restrukturisasi dan spesialisasi dengan pembentukan departemen atau instansi baru

Harinoto, adalah Dosen Prodi Manajemen Fakultas Ekonomika dan Bisnis Universitas Kanjuruhan Malang 
sebagai realisasi otonomi daerah (Abdul Wahab,2009). Dalam pelaksanaan sistem pelayanan dan efisiensi, selain sumber daya manusia, faktor-faktor yang sangat menentukan keberhasilan pembangunan daerah adalah tersedianya keuangan yang baik, bersumber dari subsidi pusat atau daerah propinsi (Abdul Wahab,2007), Arsyad (200). Pendapatan asli daerah rata-rata Kota/ Kabupaten ternyata masih relative rendah, belum dapat mendukung terselenggaranya pembangunan daerah secara baik, oleh sebab itu masih diperlukan sumber dana subsidi dari pusat dan propinsi, hampir $80 \%$ dana dari Pusat, baik subsidi maupun bantuan, mengucur ke daerah, sedangkan sisanya $20 \%$ digali dari daerahnya sendiri untuk membangun daerah (Devas, 2009).

Rendahnya kemampuan daerah membiayai program-program pembangunan disebabkan rendahnya penerimaan pendapatan daerah yang dapat digali di daerahnya sendiri. Pajak-pajak yang didesentralisasikan kepada daerah kategori pajak kecil, seperti : pajak reklame, pajak hotel dan rumah makan, pajak galian C dan pajak-pajak kecil lainnya. Sebagai konsekuensinya menyebabkan subsidi pemerintah pusat selalu meningkat dari tahun ke tahun Abdul Wahab, 2009). Gejala rendahnya kemampuan pemerintah daerah membiayai pembangunan menyebabkan pemerintah pusat menerapkan sistem sentralisasi pendanaan. Salah satu alasan utama adalah prosedur pelaksanaannya cukup sederhana dan adil. Sistem ini berhasil menjauhkan kericuhan politik antar daerah yang disebabkan oleh ketidakadilan di dalam penentuan alokasi dana dan kecemburuan sumber keuangan masing-masing daerah (Ichsan,et al, 2007). Di lain sisi, sistem ini tidak terlepas dari berbagai permasalahan yang cukup mendasar, seperti penyimpanganpenyimpangan program pembangunan pada saat pelaksanaan program (Mamesah, 2005; Davey, 2009 ). Sehingga ketergantungan kepada pemerintah pusat bisa diukur dari perimbangan keuangan pusat-daerah.

Strategi pembangunan daerah yang sentralistis, hakekatnya jebakan 'assistencialism' yang memancing masyarakat sebagai obyek asistensi dan semakin memperbesar ketergantungan masyarakat kepada pemerintah, Booth, (2003). Dengan demikian, secara perlahan-lahan dikawatirkan inisiatif dari bawah untuk merencanakan, melaksanakan dan membiayai program pembangunan menjadi kecil serta rendahnya rasa memiliki (sense of belonging) terhadap pembangunan daerahnya. Davis (2007) menyatakan perubahan kondisi kehidupan masyarakat yang ditimbulkan sebagai pengaruh dari suatu konsep ekonomi. Pajak mempunyai peranan dominan sebagai dana pembiayaan pengeluaran negara. Penggalian pajak untuk biaya pembangunan ini harus memiliki kiat lain yang semakin digalakkan.

Pajak diharapkan mampu menutupi biaya pembangunan. Keuangan penyelenggaraan pemerintahan Indonesia dalam melakukan pembangunan diperoleh dari beberapa macam pajak. Berkaitan dengan urusan pembiayaan, pembangunan, tentu tidak hanya pemerintah pusat saja. Amanat Undang-Undang No. 33 tahun 2004 bahwa pelaksanaan pembangunan itu juga merupakan kewajiban dari pemerintah daerah (Ichlasul Amal, 2003). Dengan demikian yang berhak menggali dana dari sektor pajak dan retribusi bukan hanya pemerintah pusat tetapi juga pemerintah Daerah, yang berkaitan dengan tugas pemerintah daerah otonom yang memiliki fungsi mengatur rumah tangga sendiri, melakukan pembangunan.

Seiring dengan bertambahnya tugas dan tanggung jawab daerah dalam mengatur pembangunan sendiri sebagaimana fungsi daerah otonom, maka sumber- 
sumber keuangan atau pembiayaan harus lebih ditingkatkan. Untuk urusan pembiayaan pemerintah daerah maka Pendapatan Asli Daerah (PAD) harus mencukupi untuk dipakai melakukan pembiayaan pembangunan di daerah. Daerah dapat menempuh cara- cara untuk meningkatkan Pendapatan Asli Daerah, misalnya dengan cara intensifikasi pajak, ekstensifikasi pajak ataupun dengan lebih mengoptimalkan badan-badan usaha milik daerah. Dalam menggali Pendapatan Asli Daerah (PAD) Pemerintah Kabupaten Malang, dapat mengakselerasikan dengan perekonomian daerah yang secara langsung akan berpengaruh terhadap peningkatan pendapatan daerah, Tentu rambu-rambu yang harus dipatuhi tidak melakukan upaya kontraproduktif yang dapat menimbulkan hambatan atau distorsi terhadap perekonomian dan kesejahteraan masyarakat di daerah sehingga membawa dampak high cost economy di daerah (Fernandes, 2010).

Prioritas pengembangan potensi sumber-sumber keuangan Daerah yang profitable dan masih dapat ditumbuh kembangkan di kemudian hari. Pencarian sumber Pendapatan Asli Daerah (PAD) merupakan upaya yang dilakukan terus menerus oleh Pemerintah Kabupaten Malang, hal ini perlu dilakukan mengingat belum optimalnya beberapa sumber PAD Pemerintah Kabupaten Malang. Ini menunjukkan bahwa jasa yang dapat dijual masih kurang berorientasi public service Pemerintah Daerah juga bersifat profit making (Abdul Wahab, 2007). Karena berotonomi berarti juga berotomoney, berarti menunjukkan ketidaktergantungan (khususnya dalam hal keuangan) daerah kepada pusat dalam pembangunan di daerahnya. Idealnya sumber Pendapatan Asli Daerah (PAD) mampu menyumbangkan sebagian terbesar dari seluruh pendapatan daerah dibanding sumber pendapatan lainnya, seperti subsidi dan bantuan (Arsyad, 2000).

Rumusan masalah dalam penelitian ini adalah : (a) Bagaimanakah menggali potensi sumber-sumber keuangan daerah yang potensial. (b) Bagaimanakah kontribusi Pendapatan Asli Daerah terhadap APBD. (c) Kendala-kendala dan upaya solutif yang dilakukan dalam mengoptimalkan pendapatan daerah

\section{TINJAUAN PUSTAKA}

Kaho (2002: 38) desentralisasi sebagai suatu sistem dari tugas-tugas negara diserahkan penyelenggaraannya kepada organ di daerah yang mandiri (independent). Organ ini berwenang melakukan tugas atas inisiatif dan kebijaksanaani daerahnya. Ciri desentralisasi mempunyai sumber-sumber keuangan sendiri untuk membiayai pelaksanaan tugasnya sendiri. Sementara The Lian Gie (2008) desentralisasi sebagai wujud pelimpahan wewenang dari pemerintah pusat kepada satuan pemerintahan di daerah untuk penyelenggaraan segenap kepentingan masyarakat setempat, dengan lingkungan wilayahnya disebut "Daerah Otonom", oleh satuan organisasi pemerintah itu dinamakan "otonom". Aparat pemerintah Daerah Otonom yang memegang otonomi ini disebut "pemerintah Daerah", sedangkan segenap penyelenggaraan wewenang untuk kepentingan daerah tersebut disebut kewajiban, tugas dan tanggungjawabnya tercakup dalam istilah "Pemerintah Daerah".

Penelitian Usman, M (2007) menunjukkan keseluruhan penerimaan Kabupaten/ Kota di Indonesia, bahwa pendapatan daerah (PAD) hanya menyumbangkan $\pm 10 \%$ sementara hampir $80 \%$ berasal dari subsidi dan sumbangan pemerintah pusat sisanya merupakan pinjaman daerah. Pendapatan Asli Daerah (PAD) itu sendiri komposisinya terdiri atas : Pajak Daerah (23\%), Retribusi/ pungutan jasa (49\%), Penerimaan Dinas-dinas (9\%), Laba Perusahaan Daerah (2\%) dan Penerimaan Lain-lain (17\%). Penelitian UGM bekerjasama 
dengan Depdagri (2002), kontribusi PAD terhadap total Pendapatan Daerah (APBD) th $1999 / 2000$ - th $2001 / 2002$, rata-rata sangat kecil yaitu $15,82 \%$ dalam skala nasional. Prosentase terendah ditempati Kabupaten Daerah Ambeno yaitu 0,53\% dan tertinggi adalah Kabupaten Daerah Bandung yaitu 65,29\%. Dari sebagian besar Daerah yang diteliti yaitu sebanyak 292 Daerah Tingkat PADnya hanya sebesar 5\% sampai $15 \%$ dari total Pendapatan Daerah. Hanya 2 (dua) Daerah yang PADnya diatas 50\% dari total Pendapatan Daerah., dan 54 Daerah yang mempunyai PAD di bawah 5\% dari total Pendapatan Daerahnya. Lebih jelas ditabelkan sbb:

Tabel 1.

Prosentase PAD Terhadap APBD Kabupaten/ Kota di 292 Daerah di Indonesia Tahun 2001/2002

\begin{tabular}{lll}
\hline Prosentase PAD terhadap APBD & \multicolumn{2}{c}{ Jumlah Kabupaten/ Kota } \\
\cline { 2 - 3 } $\mathbf{0 \%} \mathbf{- 1 0 \%}$ & Angka & $\mathbf{\%}$ \\
$\mathbf{1 0 , 1 \%}-\mathbf{2 0} \%$ & 86 & 41,78 \\
$\mathbf{2 1 , 1 \%}-\mathbf{3 0 \%}$ & 43 & 29,45 \\
$\mathbf{3 0 , 1 \%}-\mathbf{4 0 \%}$ & 22 & 14,73 \\
$\mathbf{4 0 , 1 \%}-\mathbf{5 0} \%$ & 17 & 7,53 \\
$\mathbf{5 0 \%}$ & 2 & 5,83 \\
Jumlah & $\mathbf{2 9 2}$ & 0,88 \\
\hline
\end{tabular}

Sumber: Hasil Penelitian Depdagri - UGM, 2001/2002

LPENI-FEUI (2003),berdasarkan data dari 289 Kabupaten/Kota kemampuan Pendapatan Asli Daerah, terlihat hanya sebanyak 3 Kabupaten/ Kota yang PAD-nya lebih besar dari rata-rata pengeluaran total dan sebanyak 6 Kabupaten/Kota yang PAD-nya lebih besar dari rata-rata pengeluaran rutin. Kabupaten/ Kota yang mempunyai kemampuan relatif besar untuk membiayai pengeluaran totalnya adalah Kota Bandung, Kota Surabaya dan Kabupaten Bandung. Sedangkan yang mempunyai PAD dapat membiayai pengeluaran rutinnya adalah Kota Semarang, Kota Denpasar, Kabupaten Bogor, Kota Bandung, Kota Surabaya dan Kabupaten Bandung. Adapun besarnya rata-rata pengeluaran total dan rata-rata pengeluaran rutin pada tahun 2008 masing-masing sebesar Rp. 67.017.000.000,- dan Rp. 45.072.000.000,-. Perbandingan Pendapatan Asli Daerah dengan rata-rata pengeluaran total dan rutinnya sebagaimana tabel berikut:

Tabel 2.

Perbandingan PAD dgn rata-rata Pengeluaran Total dan Pengeluaran Rutin Daerah Th 2003

\begin{tabular}{llll}
\hline No. & Uraian & Jumlah Kab/Kota & $\mathbf{\%}$ \\
\hline 1. & PAD $>$ rerata pengeluaran total & 3 & 1,04 \\
2. & PAD $>$ rata-rata pengeluaran total & 286 & 98,96 \\
3. & PAD $>$ rata-rata pengeluaran rutin & 6 & 2,08 \\
4. & PAD $>$ rata-rata pengeluaran rutin & 283 & 97,92 \\
& & $\mathbf{2 8 9}$ & $\mathbf{1 0 0}$ \\
\hline
\end{tabular}

Sumber : LAIEM — FEUI Tahun 2002/2003 
Kuncoro (2005), dengan data time series tahun anggaran 2002/2003 2003/2004, menunjukkan bahwa penerimaan terbesar Kabupaten/ Kota berasal dari sumbangan dan bantuan pemerintah pusat, diikuti oleh Pendapatan Asli Daerah (PAD) kemudian bagi hasil pajak dan bukan pajak. Sebagian besar Kabupaten/ Kota (173 Kabupaten/ Kota) memiliki angka presentase PAD terhadap total belanja daerah kurang dari 15\%. Komposisi PAD terdiri atas retribusi daerah $(55,67 \%)$, pajak daerah $26,6 \%)$ dan sisanya $(17,73 \%)$ bersumber dari penerimaan dinas-dinas, laba perusahaan daerah dan penerimaan lain-lain.

Penyebab-rendahnya PAD berdasarkan hasil penelitian Kuncoro adalah: (1) kurang berperannya perusahaan daerah sebagai sumber pendapatan daerah; (2) tingginya derajat sentralisasi dibidang perpajakan; (3) Kendali pajak daerah cukup beragam hanya sedikit yang bisa diandalkan sebagai sumber penerimaan; (4) alasan politis banyak orang khawatir apabila daerah mempunyai sumber keuangan yang tinggi akan mendorong terjadinya disintegrasi dan separatism; (5) kelemahan dalam pemberian subsidi dari Pemerintah Pusat kepada Pemerintah Daerah. Dengan hasil empiris penelitian ini membuktikan karakteristik otonomi daerah yang khas di Indonesia, yang berbeda dengan Negara-negara lain

\section{METODE}

Melalui pendekatan deskriptif kualitatif, dengan wawancara mendalam(indepth interview), yang didukung kajian dokumentasi dengan data time series, Penghalusan data dan informasi dengan komparasi data lain (Faisal, 2000). Cara ini sering disebut dengan negative case analysis, dilakukan dengan mencari informasi kepada orang yang sekiranya mengetahui kondisi lain serta focus group discussion secara kelompok, ditujukan kepada pegawai maupun pimpinan unit (Moleong, 2005). Data diperoleh dianalisis, narasikan serta komparasi. Reduksi tema-tema pokok yang relevan dengan penelitian.Gambaran keseluruhan penelitian diusahakan tersusun secara sistematis dengan analisis komprehensif dengan proses pengumpulan data, verifikasi dan pengambilan kesimpulan.

\section{PEMBAHASAN}

Pendapatan tahun 2011-2013 dari pajak hotel, restoran, hiburan, reklame, penerangan jalan umum, pengambilan bahan Galian Golongan C, parkir dan pajak sarang burung walet. Dengan rincian pendapatan sector Pajak dapat disajikan sebagai berikut :

Tabel 3.

Target dan Realisasi Penerimaan Pajak Daerah Tahun 2011-2013

\begin{tabular}{llll}
\hline Tahun & Target $(\mathrm{Rp})$ & Realisasi $(\mathrm{Rp})$ & Capaian $(\%)$ \\
2011 & 28.207 .500 .000 & $33,782.878 .886$ & 119.77 \\
2012 & 31.275 .000 .000 & 39.362 .653 .309 & 125.86 \\
2013 & 46.250 .000 .000 & 64.689 .653 .942 & 139.87 \\
Rata-rata & & & 128.50 \\
\hline
\end{tabular}

Sumber : DPPKAD Kabupaten Malang, 2013

Penerimaan sektor pajak daerah terjadi peningkatan dari tahun 2011 ke tahun 2013, baik dari target yang diharapkan maupun realisasinya, dengan rata-rata 
prestasi yang dicapai sebesar $128.50 \%$. Selama 3 tahun pengamatan, perkembangan yang terjadi mengalami fluktuasi. Prestasi tertinggi dicapai pada tahun 2013 sebesar 139.87\%, disebabkan kerjasama wajib pajak dan pengelola di lapangan juga beberapa tunggakan pajak yang ditagih tahun tersebut. Peringkat capaian tertinggi kedua tahun 2012 mencapai 125,86\%, karena mencapai lebih dari target yang diharapkan. Karena adanya pertumbuhan ekonomi dan beberapa jenis usaha mulai merangkak tumbuh. Implikasi lebih tinggi upaya meningkatkan pendapatan dari sector pajak dapat dicapai dan meningkatnya kesadaran yang tinggi.

Sektor Retribusi Daerah terdiri dari retribusi jasa umum, retribusi jasa usaha, serta retribusi perizinan tertentu, sebagai berikut :

Tabel 4.

Target dan Realisasi Penerimaan Retribusi Daerah 2011-2013

\begin{tabular}{llll}
\hline Tahun & Target $(\mathrm{Rp})$ & Realisasi $(\mathrm{Rp})$ & Capaian $(\mathrm{Rp})$ \\
2011 & 32.007 .444 .000 & 24.512 .496 .389 & 76.58 \\
2012 & 32.331 .912 .700 & 29.861 .750 .127 & 92.36 \\
2013 & 34.711 .520 .600 & 37.145 .935 .538 & 107,0 \\
Rata-rata & & & 91.98 \\
\hline
\end{tabular}

Sumber : DPPKAD Kabupaten Malang, 2013

Realisasi penerimaan Retribusi Daerah tahun 2011 - 2013 secara nominal mengalami fluktuasi dari target maupun realisasinya. Tahun 2011 merupakan tahun sangat jelek, tidak tercapai namun secara umum penurunan terjadi cukup berarti, mengingat deviasi yang terjadi sebesar $23.42 \%$ dari target, karena kurangnya partisipasi dari masyarakat tentang penarikan retribusi daerah, terutama jasa umum, persampahan dan kebersihan, parkir, penyuluhan dan pendidikan kepada masyarakat tentang retribusi daerah.

Capaian yang paling besar terjadi tahun 2013. karena prestasi yang dicapai menembus angka $107,01 \%$. Artinya, realisasi yang diterima capaiannya melebihi 7,01\% dari angka yang ditargetkan yaitu sebesar Rp 37.145.935.538, Tahun 2012 sisi realisasi, dibandingkan dengan target yang ditetapkan, mengalami kenaikan sedikit dari tahun sebelumnya, yaitu $\mathrm{Rp} 324.468 .700$,- dibandingkan dengan realisasi tahun 2011, mengalami kenaikan yang cukup signifikan realisasi 2012 sebesar Rp 5.349.253.738,- kondisi ini bagi petugas dilapangan dapat meningkatkan kinerja karyawan, sehingga diperlukan kajian komprehensif.

Tidak tercapainya pendapatan sector retribusi daerah ini, adanya kebijakan Pemerintah daerah menghapus beberapa jenis retribusi. Retribusi daerah pada dasarnya merupakan pungutan daerah sebagai pembayaran atas pemakaian jasa pekerjaan badan usaha milik daerah bagi yang berkepentingan atau jasa yang diberikan. Karena itu semakin banyak jasa yang diberikan semakin terbuka bagi daerah menerima hasil retribusi yang lebih besar. Retribusi dapat pula sebagai penerimaan yang diperoleh berdasarkan norma-norma umum yang ditetapkan. Norma-norma tersebut berhubungan prestasi yang diselenggarakan berhubungan dengan kepentingan umum.

Sedangkan untuk penerimaan PAD dari sektor Pendapatan Hasil Pengelolaan Kekayaan Daerah Yang dipisahkan al. penyertaan Modal pada Perusahaan Milik Daerah (BUMD) seperti PDAM, PD Jasa Yasa, Deviden Bank 
34 MODERNISASI, Volume 11, Nomor 1, Februari 2015

Jatim dan BPR Artha Kanjuruhan, dari tahun 2011 - 2013 seperti pada tabel berikut:

Tabel 5.

Target dan Realisasi Penerimaan PHPKD Yang Dipisahkan Tahun 2011-2013

\begin{tabular}{clll}
\hline Tahun & Target $(\mathrm{Rp})$ & $2011-2013(\mathrm{Rp})$ & Capaian $(\%)$ \\
2011 & 5.926 .893 .000$, & 4.920 .768 .488$, & 83.02 \\
2012 & 6.314 .003 .530$, & 6.299 .098 .670$, & 99.76 \\
2013 & 8.047 .731 .750$, & 9.084 .767 .456$, & 112.89 \\
\multicolumn{2}{l}{ Rata-rata } & & 98.56 \\
\hline
\end{tabular}

Sumber : DPPKAD Kabupaten Malang, 2013

Realisasi Pendapatan Hasil Pengelolaan Kekayaan Daerah yang dipisahkan secara nominal mengalami fluktuasi yang sangat variatif, namun dari proses perencanaan sudah cukup logis, karena tahun ke tahun ada kenaikan. Karena berdasarkan kerangka kinerja, masuk kinerja yang ideal, namun dari aspek perencanaan belum memenuhi standar yang ideal, karena tahun 2011 tidak memenuhi target yaitu kurang $16.08 \%$, tahun 2012 kurang $0.24 \%$ sudah mendekati ideal, sedangkan tahun 2013 mengalami peningkatan yang cukup signifikan, baik sisi target - realita naik $12.89 \%$ maupun sisi pendapatan dibandingkan tahun sebelumnya, naik $13.13 \%$. Penerimaan tahun 2013, lebih baik disebabkan adanya pendapatan yang berasal dari pembagian Laba BUMD, karena investasi yang dilakukan pada beberapa perusahaan BUMD merupakan investasi yang minim resiko.

Berikut untuk Lain-lain Pendapatan Asli Daerah yang sah terdiri dari pendapatan hasil penjualan Aset Daerah, penjualan Drum Bekas, Bagi hasil pengelolaan Terminal Landungsari dan biaya admin Wajib Daftar Perusahaan (WDP), kontribusi penjualan Sumber Air Bersih, Pendapatan penerimaan Jasa Giro, Pendapatan Bunga Deposito, Pendapatan Tuntutan Ganti rugi Daerah, pendapatan dari pengembalian belanja, Pendapatan dari Badan Layanan Umum Daerah (BLUD) dan pendapatan lain-lain PAD yang sah dari tahun 2011 -2013 berikut ini:

Tabel6.

Target dan Realisasi Penerimaan Lain-lain 2011-2013

\begin{tabular}{l|lll}
\hline Tahun & Target $(\mathbf{R p )}$ & Realisasi $(\mathbf{R p )}$ & Capaian (\%) \\
2011 & 50.018 .311 .000 & 90.310 .301 .774 & 180.55 \\
2012 & 53.481 .554 .147 & 54.942 .413 .501 & 102.73 \\
2013 & 53.229 .615 .176 & 61.412 .919 .063 & 115.37 \\
Rata-rata & & & 132.88 \\
\hline
\end{tabular}

Sumber : DPPKAD Kabupaten Malang, 2013

Realisasi penerimaan sektor Lain-lain yang Sah dari tahun ke tahun mengalami fluktuasi, dengan rata-rata pertumbuhan atau perkembangan sebesar $132.88 \%$. Karena keberhasilan memberdayakan yang dimiliki, sehingga prestasinya sudah cukup baik. Ini menunjukkan bahwa telah berhasil mempergunakan kesempatan yang dimilikinya (opportunity cost) untuk menanamkan sebagian dana yang dimiliki pada usaha-usaha yang dapat memberikan kontribusi positif pada penerimaan daerahnya. Sumber daya manusia 
di lingkungan Pemerintah Kabupaten Malang yang dimiliki memiliki kemampuan dalam mengembangkan dan menaksir sejumlah investasi yang dapat memberikan keuntungan optimal dengan resiko yang minimal.

\section{Analisis Tingkat Kemandirian Daerah}

Analisis ini menunjukkan kemampuan membiayai sendiri kegiatan pemerintahan, pembangunan dan pelayanan kepada masyarakat yang telah membayar pajak dan retribusi sebagai sumber pendapatan yang diperlukan daerah, ditunjukkan oleh besar kecilnya pendapatan asli daerah (PAD) dibandingkan dengan total pendapatan. Untuk mengetahui seberapa besar kontribusi Pendapatan Asli Daerah terhadap ditampilkan datanya sebagai berikut :

Tabel 7.

Kontribusi PAD terhadap Pendapatan Daerah Tahun 2011-2013

\begin{tabular}{|c|c|c|c|}
\hline Tahun & $\begin{array}{l}\text { Pendapatan Daerah } \\
\text { (Rp) }\end{array}$ & PAD (Rp) & Kontribusi (\%) \\
\hline 2011 & 1.427 .167 .882 .057 & 153.526.441.537 & 10.722 \\
\hline 2012 & 1.665.125.923.967 & 130.465.915.607 & 7.808 \\
\hline 2013 & 1.950 .582 .224 .844 & 172.333.275.999 & 8.821 \\
\hline Rata-rata & & & 9.117 \\
\hline
\end{tabular}

Sumber : DPPKAD Kabupaten Malang, 2013

Bahwa kontribusi PAD terhadap Pendapatan Daerah memiliki rata-rata sebesar $9.117 \%$. Artinya sumbangan yang diberikan kepada Pendapatan Daerah (APBD) Kabupaten Malang yang bersumber dari Pendapatan Asli Daerah (PAD) terdiri dari penerimaan hasil pajak daerah, retribusi daerah, pengelolaan kekayaan daerah yang dipisahkan dan dari penerimaan lain-lain pendapatan asli daerah yang sah, menyumbang rata-rata sebesar $9.117 \%$. Selebihnya $90.883 \%$ disumbang oleh sumber-sumber lain selain yang berasal dari PAD.

Menurut Halim (2005) ciri utama daerah mampu melaksanakan otonomi adalah (1) adanya kemampuan keuangan daerah dan kewenangan untuk menggali sumber-sumber keuangan, mengelola dan menggunakan keuangannya sendiri untuk membiayai penyelenggaraan pemerintahan; (2) ketergantungan kepada bantuan pusat harus seminimal mungkin, oleh karena itu PAD menjadi sumber keuangan terbesar yang didukung oleh kebijakan perimbangan keuangan pusat dan daerah. Semakin tinggi kontribusi Pendapatan Asli Daerah (PAD) dan semakin tinggi kemampuan daerah untuk membiayai kemampuannya menunjukkan kinerja keuangan daerah yang positif. Dalam hal ini kinerja keuangan positif dapat diartikan sebagai kemandirian keuangan daerah dalam membiayai kebutuhan daerah dan mendukung pelaksanaan otonomi daerah. Semakin tinggi derajat kemandirian suatu daerah menunjukkan semakin mampu membiayai pengeluarannya sendiri tanpa bantuan dari pemerintah pusat. Secara umum, semakin tinggi kontribusi pendapatan asli daerah dan semakin tinggi kemampuan daerah untuk membiayai kemampuannya sendiri akan dan menunjukkan kinerja keuangan daerah yang positif.

Data diatas menunjukkan tingkat kemandirian yang masih sangat minim. Artinya kemampuan PAD dalam memberikan kontribusi terhadap Pendapatan Daerah (APBD) masih dibawah angka 10\%, sebagaimana yang disampaikan 
Mahmudi (2007) bahwa kriteria kemampuan keuangan daerah dapat dikategorikan sangat baik jika nilai rasio kemandiriannya diatas 50 persen, baik jika nilai rasio 40-50 persen, cukup jika nilai rasio 30-40 persen, sedang jika nilai rasio 20-30 persen, kurang jika nilai rasio 10 - 20 persen dan sangat kurang jika nilai rasio antara $0-10$ persen.

\section{Analisis Penerimaan PAD.}

Realisasi penerimaan PAD, erat kaitannya dengan perencanaan, penetapan, penagihan, dan pengadministrasian penerimaan itu sendiri. Beberapa aspek yang menunjang peningkatan penerimaan, dengan intensifikasi, ekstensifikasi, dan diversifikasi terhadap sumber-sumber penerimaan daerah, dalam hal ini penerimaan hasil pajak daerah, hasil retribusi daerah, hasil pengelolaan kekayaan daerah yang dipisahkan dan penerimaan yang berasal dari penerimaan lain-lain pendapatan asli daerah yang sah.

Untuk melihat sejauhmana perkembangan dan tingkat keberhasilan penerimaan daerah, tentunya dengan membandingkan target penerimaan daerah terhadap realisasi yang diterima. Usahanya untuk menggali sumber-sumber keuangan daerah yang menopang APBD-nya. Target dan realisasi serta prestasi PAD Kabupaten Malang tahun 2011-2013 sebagaimana berikut:

Tabel 8.

Target dan Realisasi Penerimaan PAD 2011-2013

\begin{tabular}{c|lll}
\hline Tahun & Target (Rp) & Realisasi (Rp) & Capaian (\%) \\
2011 & 116.160 .148 .000 & 153.526 .441 .537 & 132.17 \\
2012 & 123.402 .470 .377 & 130.465 .915 .607 & 105.72 \\
2013 & 142.238 .867 .526 & 172.333 .275 .999 & 121.16 \\
Rata-rata & & & 119.68 \\
\hline
\end{tabular}

Sumber : DPPKAD Kabupaten Malang, 2013

Bahwa realisasi penerimaan PAD selama periode pengamatan telah memenuhi target dengan rata-rata perkembangan pencapaian target menembus angka 119.68\%. Namun untuk relisasi tahun 2012 mengalami penurunan sebesar Rp 22.106.525.930,- dibandingkan tahun 2011, walaupun dibandingkan dari target dan realisasi tahun 2012 sudah tercapai. Tahun 2013 selisih realisasi penerimaan PAD cukup tinggi, yaitu Rp 41.867.360.392,-bahwa PAD Kabupaten Malang masih bisa optimalkan, dengan berbagai kemungkinan antara intensifikasi dan ekstensifikasi, serta komitmen pegawai untuk memberdayakannya, masih perlu bekerja keras agar ketergantungan kepada pemerintah pusat dapat berkurang.

Pada prinsipnya penerimaan Pendapatan Asli Daerah sudah menunjukkan prestasi yang cukup baik, realisasi penerimaan sudah mencapai target yang diharapkan. Tanggung jawab pemerintah daerah harus melakukan usaha-usaha intensifikasi dan ekstensifikasi terhadap penggalian sumber-sumber pendapatan asli daerahnya guna menunjang pengeluaran yang tertuang dalam anggaran belanjanya. Kewajiban lain memenuhi hutang-hutangnya terutama hutang yang harus segera dilunasi, yaitu hutang-hutang jangka pendek, baik kepada pihak-pihak ketiga, supplier, atau pihak-pihak lain yang berasal dari internal pemerintah daerah itu sendiri.

Untuk mencapai target PAD meningkatkan kinerja aparatnya, terutama Dinas Pendapatan Pengelolaan Keuangan dan Aset Daerah yang merupakan dinas perencana dan beberapa dinas teknis yang bertanggung jawab atas penerimaan 
daerah dan tugas-tugas lainnya yang diserahkan oleh Bupati untuk mengejar target yang telah ditetapkan, baik berupa penyuluhan kepada masyarakat maupun kepada objek pajak lainnya, dan diberikan orang-orang yang dapat dipercaya untuk mengelolanya,jujur dan tidak terjadi penyelewengan dalam pelaksanaan maupun pertanggungjawabannya. Bagian pencatatan, penagihan, pembukuan dan pengawasan dipisahkan personilnya, sehingga akan menyulitkan mereka untuk merekayasa laporan yang harus dipertanggung jawabkan. Sebab masing-masing personil harus membuat laporan berdasarkan tugas dan fungsinya.

\section{Kontribusi Pajak Daerah terhadap PAD}

Analisis kontribusi Pajak Daerah terhadap PAD Kabupaten Malang selama tahun 2011 - 2013.

Tabel 9 .

Kontribusi Pajak Daerah terhadap P endapatan Daerah

\begin{tabular}{llll}
\hline Tahun & Realisasi $(\mathbf{R p )}$ & Prestasi $(\%)$ & $\begin{array}{l}\text { Kontribusi } \\
\text { PAD (\%) }\end{array}$ \\
2011 & $33,782.878 .886,-$ & 119.77 & 22.00 \\
2012 & $39.362 .653 .309,-$ & 125.86 & 30.17 \\
2013 & $64.689 .653 .942,-$ & 139.87 & 37.54 \\
\hline & & 128 & 29.90 \\
\hline
\end{tabular}

Sumber : DPPKAD Kabupaten Malang, 2013

Rata-rata penerimaan yang berasal dari pajak daerah mencapai sebesar $128.50 \%$ yang melampaui dari target yang telah ditetapkan, rata-rata kontribusi pendapatan dari pajak menembus angka 29.90\%. Terbesar tahun 2013 yang mencapai angka $37.54 \%\{(64.689 .653 .942,-/ 172.333 .275 .999,-) \times 100 \%\}$. Tertinggi kedua tahun 2012 yang mencapai angka $30.17 \% \quad\{(39.362 .653 .309$,$/ 130.465 .915 .607,-)$ x 100\% . Dan tahun 2011 mencapai $22.00 \%$ $\{(33,782.878 .886,-/ 153.526 .441 .537,-) \times 100 \%\}$.

Menurut Kamaludin (2004) Hasil Pajak Daerah dalam kaitannya dengan peningkatan pendapatan Daerah, kebijaksanaan yang perlu ditempuh adalah intensifikasi dan ekstensifikasi pemungutan pajak. Kebijaksanaan dan usaha intensifikasi peningkatan PAD dari sumber-sumber yang ada atau yang sudah berjalan selama ini. Sementara itu, kebijaksanaan dan usaha ekstensifikasi dalam pemungutan ini berupa mencari dan menggali sumber-sumber pendapatan daerah yang baru dalam batas ketentuan perundang-undangan.

Secara nominal, penerimaan dari pajak mencapai prestasi tertinggi pada tahun 2013 sebesar Rp. 64.689.653.942,-, atau dengan prestasi 139.87\% dibandingkan dengan target yang ditetapkan. Peringkat pencapaian tertinggi kedua di tahun 2012 yang mencapai Rp. 39.362.653.309,-, atau dengan prestasi $125.86 \%$ dari jumlah target yang ditetapkan. Dalam tahun 2011 yang mencapai Rp. 33,782.878.886,- atau dengan prestasi $119.77 \%$ dari jumlah target yang ditetapkan ini berarti, secara nominal pencapaian target pajak relatif cukup bagus.

Kemandirian suatu daerah dicapai dengan peningkatan pendapatan asli daerahnya, sehingga legislatif dan Kepala Daerah mampu membuat inovasi cerdas. Dengan membuat kebijakan; (1) Ekstensifikasi, dimana kebijakan ini dilakukan dalam upaya mencari /menemukan objek atau wajib pajak dan retribusi 
daerah baru ataupun juga memperluas ruang lingkup pajak yang telah ada; (2) Intensifikasi yang mana kebijakan ini memiliki makna, memanfaatkan sumbersumber yang telah ada dengan memberikan kegiatan penerangan, penyuluhan dan sosialisasi melalui berbagai media dan tenaga yang telah dipersiapkan.

\section{Kontribusi Retribusi Daerah terhadap PAD}

Analisis kontribusi Retribusi Daerah terhadap Pendapatan Asli Daerah (PAD) Kabupaten Malang selama tahun 2011 -2013

Tabel 10.

Kontribusi Retribusi Daerah terhadap PAD th 2011-2013

\begin{tabular}{llll}
\hline Tahun & Realisasi (Rp) & Prestasi (\%) & $\begin{array}{l}\text { Kontribusi thd PAD } \\
\mathbf{( \% )}\end{array}$ \\
2011 & 24.512 .496 .389$, & 76.58 & 15.966 \\
2012 & 29.861 .750 .127$, & 92.36 & 22.888 \\
2013 & 37.145 .935 .538$, & 107,01 & 21.554 \\
Rata-rata & & 91.98 & 20.136 \\
\hline
\end{tabular}

Sumber : DPPKAD Kabupaten Malang, 2013

Dari hasil analisis data yang di tabelkan tersebut di atas, penghitungan target dan realisasi penerimaan yang berasal dari Retribusi Daerah menunjukkan angka yang cukup signifikan pada tahun 2011 yang mencapai $15.966 \%$ dalam memberikan sumbangan penerimaan terhadap PAD. Tahun 2012, memberikan sumbangan terhadap PAD sebesar 22.888\%. Dan pada tahun anggaran 2013 memberikan sumbangan terhadap PAD sebesar 21.554\%. Dan jika diambil ratarata kontribusi penerimaan retribusi daerah terhadap PAD mencapai angka $20.136 \%$. Kontribusi terbesar terjadi pada tahun 2012, yang mencapai angka $22.888 \%\{(29.861 .750 .127,-/ 153.526 .441 .537,-) \times 100 \%\}$. Berikutnya kontribusi tertinggi kedua terjadi pada tahun 2013 yang mencapai angka $21.554 \%$ $\{(37.145 .935 .538,-/ 172.333 .275 .999) \times 100 \%\}$. Dan terakhir terjadi pada tahun 2011 yang mencapai $15.966 \%\{(24.512 .496 .389,-/ 153.526 .441 .537) \times 100 \%\}$.

Retribusi daerah pada dasarnya merupakan pungutan daerah sebagai pembayaran atas pemakaian atau karena memperoleh jasa pekerjaan badan usaha milik daerah bagi yang berkepentingan atau karena jasa yang diberikan oleh pemerintah daerah. Oleh karena itu semakin banyak jasa yang diberikan oleh pemerintah daerah akan semakin terbuka bagi daerah untuk menerima hasil pungutan retribusi yang lebih besar. Secara lebih mendalam retribusi dapat diartikan pula sebagai penerimaan yang diperoleh penguasa publik dari rumah tangga swasta berdasarkan norma-norma umum yang ditetapkan. Norma-norma tersebut berhubungan dengan prestasi-prestasi yang diselenggarakan atas usul dan kepentingan swasta, sedangkan prestasi tersebut berhubungan dengan kepentingan umum.

Pengelolaan terhadap retribusi daerah harus dapat dilakukan secara cermat, tepat dan hati-hati. Pemerintah daerah perlu memiliki sistem pengendalian yang memadai untuk menjamin ditaatinya prosedur dan kebijakan manajemen yang telah ditetapkan agar masyarakat dapat mentaati aturan yang berlaku dalam pembayaran retribusi. 


\section{Kontribusi HPKD yang Dipisahkan terhadap PAD}

Analisis kontribusi HPKD yang dipisahkan terhadap PAD Kabupaten Malang, yang disajikan dengan data Target dan Realisasi Hasil pengalolaan Kekayaan Daerah yang dipisahkan selama tahun 2011 -2013 adalah

Tabel 11.

Kontribusi Pendapatan HPKD Yang Dipisahkan terhadap PAD 2011-2013

\begin{tabular}{lllll}
\hline Tahun & Realisasi (Rp) & Prestasi (\%) & $\begin{array}{l}\text { Kontribusi } \\
\text { PAD }(\%)\end{array}$ & terhadap \\
2011 & $4.920 .768 .488,-$ & 83.02 & 3.205 \\
2012 & $6.299 .098 .670,-$ & 99.76 & 4.828 \\
2013 & $9.084 .767 .456,-$ & 112.89 & 5.271 & \\
Rata-rata & & 98.56 & 4.435 \\
\hline
\end{tabular}

Sumber : DPPKAD Kabupaten Malang, 2013

Data diatas menunjukkan bahwa kontribusi Pendapatan Hasil Pengelolaan Kekayaan Daerah Yang Dipisahkan terhadap PAD masih sangat kecil, mengingat rata-ratanya hanya mencapai $4.435 \%$.Kontribusi terbesar terjadi pada tahun 2013 , yang mencapai angka 5.271\% $\{(9.084 .767 .456,-/ 172.333 .275 .999,-) \times 100 \%\}$. Berikut tahun 2012 kontribusinyasebesar $4.828 \%\{(6.299 .098 .670,-\quad$ / $130.465 .915 .607,-) \times 100 \%\}$. Dan terakhir terjadi pada tahun 2011 yang mencapai $3.205 \%\{(4.920 .768 .488,-$ / 153.526.441.537) x 100\% $\}$ hasil perusahaan milik Daerah dan hasil Pengelolaan kekayaan milik Daerah yang dipisahkan merupakan penerimaan Daerah yang berasal dari hasil perusahaan milik Daerah dan pengelolaan Kekayaan Daerah yang dipisahkan, sehingga diperlukan suatu upaya strategis untuk meningkatkannya. Menurut Halim, jenis pendapatan ini meliputi objek pendapatan berikut: 1) bagian laba Perusahaan milik Daerah, 2) bagian laba lembaga keuangan Bank, 3) bagian laba lembaga keuangan non Bank, 4) bagaian laba atas penyertaan modal/investasi. Seperti tergambar dalam APBD Kabupaten Malang.

\section{Kontribusi Lain-lain yang sah terhadap PAD Kabupaten Malang}

Analisis kontribusi lain-lain yang sah terhadap PAD Kabupaten Malang, yang disajikan dengan data Target dan Realisasi lain-lain Pendapatan ASli Daerah selama tahun $2011-2013$

Tabel 12.

Kontribusi lain-lain yang sah terhadap PAD Kabupaten Malang 2011-2013

\begin{tabular}{llll}
\hline Tahun & Realisasi (Rp) & Prestasi (\%) & $\begin{array}{l}\text { Kontribusi terhadap PAD } \\
(\%)\end{array}$ \\
2011 & $90.310 .301 .774,-$ & 180.55 & 58.824 \\
2012 & $54.942 .413 .501,-$ & 102.73 & 42.112 \\
2013 & $61.412 .919 .063,-$ & 115.37 & 35.636 \\
Rata-rata & & 132.88 & 45.524 \\
\hline
\end{tabular}

Sumber : DPPKAD Kabupaten Malang, 2013 
Dari hasil analisis yang ditabel di atas dapat dijelaskan bahwa kontribusi Pendapatan lain-lain yang sah terhadap PAD Kabupaten Malangpaling tinggi dibanding dari pendapatan yang lainnya (dari Pajak, retribusi, pengelolaan kekayaan Daerah yang dipisahkan) , mengingat rata-ratanya mencapai 45.524\%.Kontribusi terbesar terjadi pada tahun 2011, yang mencapai angka $58.824 \%\{(90.310 .301 .774,-/ 153.526 .441 .537,-\mathrm{x} 100 \%\}$. Berikut tahun 2012 kontribusinyasebesar $42.112\{54.942 .413 .501,-/ 130.465 .915 .607,-) \times 100 \%\}$. Dan terakhir terjadi pada tahun 2013 yang mencapai $35.636\{61.412 .919 .063,-/$ 172.333.275.999,-)) x 100\%\}.

Dari kondisi di atas, menggambarkan bahwa, hasil lain-lain yang sah terhadap PAD Kabupaten Malang merupakan penerimaan Daerah yang berasal dari pendapatan hasil penjualan asset Daerah yang tidak dipisahkan, penjualan Drum bekas, bagi hasil pengelolaan terminal Landungsari, biaya admin Wajib Daftar Perusahaan (WDP), penerimaan jasa Giro, pendapatan Bunga Deposito, pendapatan tuntutan ganti rugi Daerah, dan pendapatan lainnya sehingga diperlukan suatu upaya strategis untuk meningkatkannya.

\section{Pembahasan}

Kebijakan mengenai peningkatan Pendapatan Asli Daerah tersebut nampaknya sangat terkait dengan pola hubungan fiskal antara pemerintah pusat dengan pemerintah daerah. Secara umum, kebijakan peningkatan Pendapatan Asli Daerah yang dilakukan oleh Pemerintah Kabupaten Malang dibagi menjadi dua bentuk kebijakan yakni, Intensifikasi dan Ekstensifikasi. Intensifikasi dimaksud sebagai kebijakan dari Pemerintah Daerah meningkatkan sumber-sumber yang telah ada, sehingga dapat memberikan hasil yang lebih maksimal. Sedangkan Ekstensifikasi dimaksudkan sebagai kebijakan pemerintah daerah untuk mencari dan menggali sumber-sumber penerimaan baru dalam batas kewenangan yang ada.

Sehubungan dengan kondisi diatas, maka kiat-kiat yang dapat dilakukan pertama, melakukan penyuluhan meningkatkan kesadaran masyarakat memenuhi kewajibannya membayar pajak dan retribusi daerah, karena pendapatan dari pajak dan retribusi memberikan sumbangan terbesar dalam perolehan PAD, kedua, pembinaan dan pengawasan terhadap petugas pajak dan retribusi daerah, ketiga, pendataan objek/subjek pajak dan retribusi daerah, dan keempat, penagihan secara aktif baik pajak atau retribusi tahun berjalan maupun tahun sebelumnya.

\section{Upaya Intensifikasi dan Ekstensifikasi Sumber-Sumber Potensial PAD}

Upaya yang dilakukan dalam mengelola sumber potensi PAD untuk meningkatkan kemampuan keuangan daerah dengan memperhatikan kecenderungan mengenai target dan realisasi penerimaan daerah di masa lalu dan perkembangan ekonomi daerah terutama yang berkaitan dengan bentuk kegiatan ekonomi masyarakat. Seringkali dijumpai keadaan dimana penentuan target penerimaan PAD tidak didasarkan pada rumusan yang jelas, sehingga besarnya target satu periode anggaran ke periode anggaran berikutnya tidak mengikuti trend yang "smooth", melainkan mengikuti gerakan yang fluktuatif. Dengan berlandaskan pada pemikiran tersebut, maka perumusan target suatu item pajak, sehingga diperlukan usaha-usaha intensifikasi.

Disamping didasarkan pada pola kecenderungan penetapan target, usaha intensifikasi dari suatu item PAD juga bisa didasarkan pada pola kecenderungan realisasi, perbaikan sistem pemungutan maupun sistem pendataan potensi, melakukan pemungutan lebih giat, ketat dan teliti mencakup aspek-aspek kelembagaan, ketatalaksanaan, dan aspek personalianya, berikut perangkat- 
perangkatnya sesuai sistem dan prosedur MAPATDA, (Kepmendagri No 102/ 2000). Meningkatkan kerjasama Badan Perijinan Terpadu, melaksanakan Opsi (Operasi Yustisi), melaksanakan evalusi penerimaan Pajak daerah, meningkatkan pengawasan benda Berharga (Karcis, SKPD, dan lain-lain) sebagai alat pemungutan pajak daerah, menjalin kerjasama yang baik dengan PLN terkait Pajak Penerangan Jalan Umum (PPJU)

Usaha-usaha ekstensifikasi, dengan menemukan sumber pendapatan potensial yang belum dieksploitasi. Kegiatan ekonomi masyarakat merupakan langkah awal menemukan sumber-sumber pajak atau retribusi baru yang bisa dikembangkan, al. usaha baru yang belum terdaftar sebagai Wajib Pajak, memberikan sosialisasi Pajak daerah kepada masyarakat melalui media, seperti brosur, spanduk, pamflet, banner dan standing banner, mengadakan evaluasi Perda tentang pajak daerah yang sudah ada, antara lainFutsal dan Squash adalah jenis olah raga baru yang banyak diminati oleh masyarakat, dapat ditarik pajak hiburan.

Secara eksplisit ekstensifikasi diatur UU no 18 Tahun 2007 tentang Pajak Daerah dan Retribusi Daerah yang telah diubah dengan Undang-Undang Nomor 34 tahun 2000. Menurut Kaho (2008:60), "setidaknya ada empat faktor yang mempengaruhi pelaksanaan otonomi daerah, yaitu : Keuangan harus cukup baik, manusia pelaksananya harus baik dan cukup, peralatannya harus baik dan cukup, serta organisasi dan manajemennya harus baik". The Liang Gie (2006:33), mengatakan bahwa pada prinsipnya daerah otonom harus dapat membiayai sendiri semua kebutuhan sehari-hari yang rutin, apabila untuk kebutuhan itu daerah masih mengandalkan bantuan dari pusat, maka sesungguhnya daerah itu tidak otonom lagi, penerimaan keuangan daerah yang bersumber dari PAD masih belum mampu memberikan kontribusi yang signifikan terhadap Pendapatan Daerah. Banyak hal yang dapat dijelaskan dengan kondisi yang menunjukkan kurang signifikannya penerimaan PAD terhadap Pendapatan Daerah Kabupaten Malang.

Dari hasil penelitian lain menyebutkan bahwa kebijakan mengenai peningkatan pendapatan asli daerah Kabupaten Malang tidak terlepas dari pola hubungan fiskal antara pemerintah pusat dan daerah. Pola hubungan semacam ini tidak lain adalah terkait dengan model kebijakan desentralisasi seperti tertuang dalam Undang-Undang Nomor 32 dan 33 tahun 2004.

Karena pemerintah pusat sering bertindak sebagai inisiator, maka tidak heran kalau sebagian besar sumber keuangan masih dikuasai oleh pemerintah pusat sehingga kemandirian fiskal daerah sangat sulit untuk diwujudkan (Booth, 2003). Hal demikian juga terjadi pada kebijakan desentralisasi fiskal.Proses perumusan kebijakan peningkatan Pendapatan Asli Daerah selalu diidentifikasikan oleh masing-masing Dinas/Unit penghasil Pendapatan Asli Daerah, karena dinas-dinas tersebut yang lebih mengetahui dan merasakan persoalan-persoalan tehnis maupun non tehnis dalam pemungutan sumber-sumber Pendapatan Asli Daerah yang dikelolanya.

Formulasi kebijakan peningkatan Pendapatan Asli Daerah di tingkat eksekutif tidak langsung disahkan atau diferifikasikan, namun harus melalui tahap pembahasan di tingkat legislatif, selanjutnya disahkan oleh Bupati dan DPRD untuk diimplementasikan. Abdul Wahab (2009) menyarankan kajian yang cermat dan sistematik atas political feasibility (kelayakan politik) merupakan salah satu cara untuk mengatasi timbulnya ganjalan-ganjalan dalam proses perumusan serta implementasi kebijakan. 
Relevansinya dapat ditunjukkan dengan adanya perlawanan dari kelompok sasaran kebijakan, mengeluarkan kebijakan Intensifikasi Pendapatan Asli Daerah, dengan menaikkan tarif pajak/retribusi. Hal ini mengindikasikan selain kurangnya sosialisasi, dalam perumusan kebijakan sangat kurang melibatkan para wakil rakyat sehingga kajian yang cermat akan kelayakan politiknya terabaikan dan ganjalan-ganjalan implementasinyapun juga semakin bermunculan.

\section{Inisiator, Formator dan Implementator Kebijakan Peningkatan Pendapatan Asli Daerah}

Berdasarkan hasil survey, ditemukan bahwa proses implementasi kebijakan peningkatan Pendapatan Asli Daerah secara dominan peran dari inisiator, formator dan implementator dilakukan oleh lembaga eksekutif melalui dinas/unit kerja penghasil Pendapatan Asli Daerah ketimbang lembaga Legislatif yang mewakili jaringan kekuatan politik lokal. Hal ini dapat berdampak buruk pada proses implementasinya sebagaimana dikemukakan oleh Abdul Wahab (2007), bahwa proses implementasi kebijakan itu sesungguhnya tidak hanya menyangkut badan-badan administratif yang melaksanakan program, melainkan menyangkut jaringan kekuatan politik yang mempengaruhi semua pihak yang terlibat. Sehingga agar implementasi kebijakan dapat mencapai apa yang diharapkan, maka seak proses perumusannya diperlukan peranan jaringan kekuatan-kekuatan politik lokal yang dalam hal ini DPRD Kabupaten Malang.

Lembaga eksekutif sebagai implementator kebijakan Pendapatan Asli Daerah berperan aktif dalam proses reformulasi kebijakan, dan kontrol secara cermat oleh lembaga legislatif sebagai inisiator dan formator kebijakan dalam proses perumusan kebijakan.

\section{KESIMPULAN}

a. Sumber-sumber potensi keuangan daerah sektor pajak daerah, trent penerimaan terjadi peningkatan dari tahun 2011 ke tahun 2013, baik dari sisi target yang diharapkan maupun realisasinya, dengan rata-rata prestasi yang dicapai sebesar $128.50 \%$. Retribusi Daerah, mengalami trent peningkatan yang relative baik, dari target ke target maupun realisasi ke realisasi. Namun masuk kategori sangat fluktuasi dilihat dari target ke realisasi. Prestasinya rata-rata capaian 91.98\%Pendapatan Hasil Pengelolaan Kekayaan Daerah Yang Dipisahkan,trent-nya mengalami peningkatan, baik dari sisi target ke target mapun dari sisi realisasi ke realisasi. Namun sisi target ke realisasi belum memenuhi target yang ditetapkan.Lain-lain Pendapatan Asli Daerah yang Sah, mengalami fluktuasi, perkembangan sebesar $132.88 \%$.

b. Kontribusiterhadap Pendapatan Daerah (APBD) memiliki rata-rata sebesar $9.117 \%$. Artinya sumbangan yang diberikan sebesar 9.117\%. Selebihnya sebesar $90.18 \%$ disumbang oleh sumber-sumber lain selain yang berasal dari PAD. Sehingga jika ditinjau dari tingkat kemandirian daerah, maka hasil perhitungan diatas, menunjukkan tingkat kemandirian yang masih sangat minim.

c. Kendala- kendala yang dihadapi mengoptimalkan penerimaan PAD, menyangkut sspek kelembagaan dengansistem MAPATDA sehingga informasi belum cepat dan akurat. Sistem pengawasan belum berjalan optimal. Aspek ketatalaksanaan, belum berjalan sebagaimana mestinya, pengawasan dan pengendalian belum optimal.

\section{Saran-saran}


1. Perlunya mengupayakan untuk mengeliminir tingkat kebocoran dan penagihan pajak daerah, agar pajakyang belum optimal dapat ditingkatkan kembali, melalui intensifikasi dan ekstensifikasi, tersedianya sarana dan prasarana yang memadai untuk kegiatan operasional di lapangan, mengefektifkan sistem pengendalian dan pengawasan di lapangan, mengupayakan tesedianya data dasar guna menggali potensi sumber-sumber penerimaan, terutama dari pajak daerah.

2. Intensifikasi pajak daerah dengan memperbaiki / menyesuaikan aspek kelembagaan (DPPKA), aspek ketatalaksanaan, baik administrasi maupun operasional, meningkatkan pengawsan dan pengendalian, dan meningkatkan kegiatan penyuluhan kepada masyarakat secara luas.

3. Ekstensifikasi pajak daerah dengan menemukan sumber pendapatan potensial yang belum dieksploitasi.

4. Melakukan penelitian-penelitian lebih lanjut tentang objek-objek penerimaan yang berpotensi perluasan sumber-sumber penerimaan PAD yang masih menjadi wewenang Pemerintah Daerah dan tidak bertentangan dengan peraturan perundangan.

\section{DAFTAR PUSTAKA}

2000: Kepmendagri No 102/ 2000 tentang Sistem dan Prosedur Perpajakan, Retribusi Daerah dan Pendapatan Daerah Lainnya serta Pemungutan Pajak Bumi dan Bangunan di Kabupaten / Kota Daerah seluruh Indonesia

......., 2013: Dokumen Dinas Pendapatan dan pengelolaan Keuangan dan Anggaran (DPPKAD) Kabupaten Malang

......., 2002: Depdagri dan UGM, Kontribusi PAD terhadap Totap Pendapatan Daerah (APBD) 2001-2002

......, 2003: LPENI-FEUI, Kemampuan Pendapatan Asli Daerah mendukung Pembangunan di Kabupaten dan Kota di Indonesia

......., 2007, Analisis Kebijakan Publik: Dari Formulasi ke Implementasi Kebijakan Negara, Jakarta : Bumi Aksara.

Abdul Wahab, Solichin, 2009, Analisis Kebijakan Publik Teori dan Aplikasi, Malang : Danar Wijaya

Arsyad, Nurdjaman, 2000, Hubungan Fiskal antar Pemerintah di Indonesia, Peranan dan Masalahnya, dalam analisis CSIS No. 3 Tahun XIX / 2001, CSIS, Jakarta.

Booth, Anne, 2003, Upaya-upaya untuk Mendesentralisasikan Kebijakan Perpajakan Kemampuan Perpajakan, Usaha Perpajakan, dan Perimbangan Keuangan, dalam Collin McAndrews dan Ichlasual Amal (ed) Jakarta : Rajawali Press.

lchlasul Amal, 2003, Hubungan Pusat Daerah dalam Pembangunan, Cetakan Pertama, Raja Grafindo Persada, Jakarta.

Davey, Kenneth, 2009, Pembiayaan Pemerintah Daerah, terjemahan Ammanullah, Jakarta : UI-Press. 
44 MODERNISASI, Volume 11, Nomor 1, Februari 2015

Devis, Nick, 2007, Keuangan Pemerintah Daerah di Indonesia, Terjemahan Masri Maris, Cetakan 1, UI-Press Jakarta.

Faisal, Sanapiah, 2000, Penelitian Kualitatif Dasar-dasar dan Aplikasi, YA3, Malang.

Fernandes, Yohanes, 2010: Mencari Bentuk Otonomi Daerah dan Upaya Memacu Pembangunan Regional di Musa Depan, PT Gramedia Pustaka Utama, Jakarta.

Gie, The Liang, 2008, Administrasi Public, Jakarta : PT Gunung Agung.

Ibnu Rejo, S., 2005, Pentingnya Intensifikasi dan Ekstensifikasi Pendapatan AsliDaerah untuk Meningkatkan Otonomi Kabupaten/ Kota, Makalah Seminar Nasional AIPI XIII, 1-3 Nopember 2005 di Bangpinang, Riau.

Ichsan, Moch, dkk, 2007, Administrasi Keuangan Daerah Pengelolaan dan Penyusunan Anggaran Pendapatan dan Belanja Daerah (APBD), PT. Danar Wijaya, Brawijaya University Press.

Kamaluddin, Rustian, 2004, Keuangan Daerah Kotamadya Padang Panjang: Profil, Potensi dan Pengembangan dalam Ekonomi dan Keuangan Indonesia, Vol. XXIXI No. 1, Maret 2004, LPEM, FEUI, Jakarta.

Kuncoro, 2005: Penerimaan Pendapatan Asli Daerah (PAD) Pemerintah Kabupaten dan Kota di Indonesia

Halim, Alfians, 2005, Pendapatan Daerah dalam Ekonomi Orde Baru, Prisma, No. 4, April 2005, LP3ES Jakarta.

Moleong, 2005: Metode penelitian kualitatif sebagai sarana penelitian ilmiah, Rajawali Press, Jakarta.

Nugroho, Trilaksono, 2000, Reformasi dan Reorientasi Kebijakan Otonomi Daerah dalam Perspektif Hubungan Pemerintah Pusat-Daerah, Jurnal Administrasi Negara, Vol. 1 No. I Malang : FIA Unibraw.

Kaho, Riwu, 2007: Prospek Otonomi Daerah di Negara Republik Indonesia, Rajawali Press, Jakarta.

Usman, M. 2007, Peran Pendapatan Asli Daerah (PAD) dalam Anggaran Pendapatan dan Belanja Daerah (APBD), Tesis Pascasarjana Universitas Brawijaya Malang 